\title{
NANOTECHNOLOGY: LEGAL AND ETHICAL ISSUES
}

\author{
AgNIESZKA BARAN
}

\begin{abstract}
A B S T R A C T
Nanotechnology is a very vast field which includes a range of technologies at the nano scale, such as pharmaceuticals, biotechnology, genomics, neuroscience, robotics and information technologies. Nanotechnology is the latest technological innovation in global debates on risk regulation and international cooperation. Regulatory bodies have started dealing with the potential risks posed by nanoparticles. Since 2004 the UE has been developing a regulatory policy to tighten control and to improve regulatory adequacy and knowledge of nanotechnology risks. Currently, specific provisions on nanomaterials have been introduced for biocides, cosmetics, food additives, food labelling and materials in contact with foodstuff. The statement that nanotechnologies do inevitably imply ethical questions. The main problems are public trust, potential risks, issues of environmental impact, transparency of information, responsible nanosciences and nanotechnologies research. The aim of this article is to analysis the main problems regulating nanotechnology and some aspects of ethics.
\end{abstract}

KEY WORDS

nanotechnology, regulation, risk, ethical issues

DOI: 10.1515/emj-2016-0005
Corresponding author: Agnieszka Baran
Bialystok University of Technology Faculty of Management e-mail: a.baran@pb.edu.pl

\section{INTRODUCTION}

Nanotechnology is an area which has been subject to dynamic development in recent years. Individual countries are increasing spending on research and development in this field. The solutions offered by nanotechnology are used in such areas of life as, among others, medicine, electronics, energetics, food industry, information technology, astronautics, communication. Nanotechnology is defined as a dual-use technology, due to the fact that it brings with it both the opportunities for progress and the development of mankind, but also may pose a serious threat to the health and life of humans and the environment (Dorocki \& Kula, 2015, p. 28). It is a very young field, and the impact of nanomaterials on human bodies and the environment, especially in the long term, it is not always known. Nanomaterials may exhibit enhanced biological activity as they easily penetrate biological membranes. Nanoparticles may therefore exhibit toxic properties, posing a threat to humans and animals. Currently, the largest risk associated with nanotechnology is connected to the lack of control over it, there are no technical means to monitor for example the environment for the presence and impact of nanoparticles and nanomaterials. There is still no adequate legislation, even though since 2004 the European Union (EU) has introduced provisions relating to nanotechnology. Nanotechnology is an area, which has been subject to dynamic development in recent years. The aim of EU legislation is to provide public access to innovative applications of nanotechnology, along with ensuring the safety, as well as protection of health and the environment. Increasingly, there also appears the issue of the ethical aspects in the field of nanosciences and nanotechnologies.

The aim of this article is to examine the legal and ethical aspects of the safety of nanomaterials usage. In particular, it presents the possibilities of regulating 
the issue of the safety of nanomaterials and the related ethical issues.

\section{LITERATURE REVIEW}

In international literature, the primarily raised question is the one whether nanotechnology should be included in the legal framework or whether the socalled soft law mechanisms can be used? Currently, in relation to nanomaterials, within the European Union we are dealing with both the legal acts with binding force (regulations, directives), as well as non-binding acts such as recommendations concerning the fair conduct of scientific research or the application of a uniform definition of nanomaterial. Since nanotechnology has been within the interests of the European legislator for almost twenty years, it is also the subject of discussions regarding the legal doctrine. There has been a different approach to the matter of regulation of nanotechnology. Some authors see the possibility of influencing the strengthening of the safety of use of nanomaterials, through non-judicial means (Maatsura, 2006). Due to the dynamics of change in this area, some people see an urgent need for the use of soft law (Brazell, 2012). Soft law includes resolutions, guidelines, explanations, messages, programs, plans, mostly issued by the authorities involved in the legislative processes, the result of which is a generally applicable legislative act. Construction of soft law instruments is intended to constitute a foundation for the future hard legal regulations. Also important are the voluntary programs aimed at gathering information useful for the design of legal instruments (Malloy, 2012). According to the position of EU bodies, some authors suggest the strengthening of the existing forms of cooperation in the field of nanotechnology and cheering for States to build internal legal regulations (Falkner et al., 2010). Relevant legal regulations in the European Union do not relate directly to nanotechnology, which is why new tools should be created in order to prevent the possible harmful effects of the use of nanomaterials (Ponce del Castillo, 2010). The view regarding the possibility of the future creation of a division of law of a collective nature is not often presented as it may take place only under the condition of attainment of full knowledge regarding the properties of nanomaterials (Oud, 2007). The most important problems in the sphere of nanotechnologies which should be soon resolved have been indicated. It is a question of applying a uniform definition of the nanomaterial, development of metrology tools in relation to nanomaterials, development of safety tests and risk assessment methodologies (Porter et al., 2012).

A difficult issue is the ability to regulate nanotechnology at the international level, under the Future Framework Agreement (Marchant \& Doug, 2006). Some authors are unanimous about the fact that the regulation of nanotechnology at the international level is a big challenge because of the different ways of the use of nanomaterials. It seems, however, that in the future comprehensive regulations in the field of nanotechnology will be created. It may be significantly affected by the creation of the best practices for dealing with nanomaterials, which will be applied at the international level (Baran, 2015, p. 37).

Nanotechnologies constitute an interdisciplinary subject, which translates into a very broad spectrum of potential applications. Nowadays nanotechnologies encompass most areas of the sphere of technology. The literature also mentions the need to regulate the aspects of intellectual property in the context of nanotechnology (Balcerzak, 2013; Ganguli \& Jabade, 2012; Cisneros, 2009; Fischer, 2005). Moreover, the number of discussion on the ethical aspects of nanotechnology development has increased recently. (Sandler, 2009, pp. 13-16). Also, in the context of the patent law, the question is posed whether the nanotechnology inventions should be excluded from patenting because of the unknown potential risks to human health or the environment, just as in the case of inventions in the field of biotechnology (Witek, http://wtspatent.pl/). In the literature, there appears the concept of nano-ethics, which is defined as moral reflection on the development and application of nanotechnology, or the manipulation of matter at the molecular level. In this regard, dilemmas regarding the potential harmfulness of nanoparticles are beginning to appear. In the case of nanotechnology, questions are raised about their availability and impact on the welfare of mankind. There arises a justified fear that nanotechnology will become another element strengthening the division of the world into developed countries and the ones lagging behind or these in control and the controlled ones (Bazela, 2008). 


\section{LEGAL REGULATION IN THE FIELD OF NANOTECHNOLOGY}

Nanosciences and nanotechnologies have been present in the strategic documents of the European Union for at least twenty years. The European Commission (EC) Communication „Nanosciences and nanotechnologies: An action plan for Europe for the years 2005-2009. In Second Implementation Report for the years 2007-2009" it was found that nanotechnology offers significant potential to improve the quality of life and the competitiveness of industry in Europe. Its development and use should not be delayed, unbalanced or left to chance (COM (2009) 607). At the time, an initial review of the legal framework in the field of nanotechnology was performed to examine whether new regulatory action was required to cover the risks in relation to nanomaterials. Preliminary results showed that the existing provisions in principle included the health issues and environmental impact. The regulatory authorities of the Member States were commissioned to assess the national legislation and identify gaps in it. Even then a preventive approach in the field of nanotechnology was recommended, due to the absence of complete knowledge about nanomaterials, it was recommended to use the existing legal mechanisms in relation to thresholds, the authorization of substances and ingredients, qualification of hazardous waste, reinforcing conformity assessment procedures, restrictions on the introduction of chemical substances and preparations to the market and their use. In 2009, the European Parliament (EP) passed a report on regulatory aspects of nanomaterials, taking also into account the Commission Communication of 17 June 2008 entitled „Regulatory aspects of nanomaterials” (COM (2008) 366). The report shows that the European Commission sees the benefits of nanotechnology development but at the same time is aware of the risks arising from this development for humans and the environment. The EC confirmed the absence of complete knowledge about the potential risks posed by nanomaterials, and the evidence relating to the risks caused by certain nanomaterials and the overall lack of methods for the proper assessment of the risks associated with raising concerns about nanomaterials. In the context of many doubts concerning the use of nanomaterials, there appears an urgent need to include this sphere into the legal framework. Therefore, the European Commission, starting from 2008, has been reviewing the existing regulations concerning the use of nanomaterials, and has indicated the actions that ought to be taken in the future. The European Commission, in the second regulatory review dedicated to nanomaterials, emphasizes the need to improve EU law in order to ensure the safe use of nanomaterials. The communication highlights the diverse nature and types of nanomaterials, ranging from everyday materials used for decades (for example in tires or as anticoagulants in foodstuffs) to highly sophisticated materials used in industry and cancer therapies. More and more is known about the hazardous properties of nanomaterials. They do not succumb to categorization, and this justifies the need to carry out assessments of the risk associated with particular applications. The European Commission, stresses that an individual approach should be applied to risk assessment, using strategies based on the information about the potential risks in respect of exposure or hazard. In recent years we have seen undertaking legislative work to regulate the use of nanomaterials by a majority of Member States.

The current regulations, as regards the application of nanomaterials, consist mainly of two regulations, the so-called REACH (Registration, Evaluation and Authorisation of Chemicals) ((EC) No 1907/2006) and CLP (Classification, Labelling and Packaging) ((EC) No 1272/2008). The provisions on nanomaterials can also be found in sectoral regulations. The regulations concerned the use of biocides, cosmetic products ((EC) No 1223/2009), transmission of information to consumers about food and food additives ((EC) No 1169/2011). Since nanotechnologies are also used in medicine, a Directive on the Community Code relating to medicinal products for human use (Directive 2001/83/EC) appeared in 2001. The procedures for the authorization of medicinal products have also been defined ((EC) No 726/2004). To ensure safety it is advisable to compile a register of nanomaterials and products containing nanomaterials, such a register will facilitate the supervision of entities introducing nanomaterials to the market and ensure the transparency of data on products for buyers. At the moment such an obligation is relevant for cosmetic products (Jurewicz, 2014, p. 172).

It should be recognized that the European Union has been consistently working on regulation nanotechnology. In the international arena, activities 
are also undertaken to regulate nanotechnology. The potential risks arising from the development of this area are seen by many states. In the United States in 2008, the US National Research Council issued a report calling for greater regulation of nanotechnology.

Australia and Canada are also rather active on nanoregulation. Both have important programmes on Environmental Health and Safety (EHS) research and have published in-depth reviews of their regulations to assess eventual limits when dealing with nanotechnology. Even though no specific laws have been set up, the adoption of a precautionary approach principle, when dealing with nanotechnology application, is envisaged in both countries. In Japan, China, Korea and Taiwan, which are deeply involved in nanotechnology, there are also, at different levels, important research initiatives dealing with EHS issues such as risk assessment and risk management of nanomaterials and nano-related products. They do participate in the worldwide debate on nanoregulation but no specific initiatives on the matter have been taken so far in these countries (http://www.nanowerk.com, 12.01.2016).

Currently, the actions to regulate nanotechnology focus on the national level, and at the international level initiatives of the nature of joint research programs are observed.

\section{PRECAUTIONARY PRINCIPLE AS A BASIS FOR THE REGULATION OF NANOTECHNOLOGY}

In view of the current knowledge, nanomaterials resemble natural substances in the respect that some of them may be toxic, while others may not. The possible risk is related to specific nanomaterials and specific applications. Therefore, in the case of nanomaterials there is a need of risk assessment that should be carried out on case by case basis with the use of relevant information. The biggest challenge at the moment is primarily related to the establishment of the validated methods and instruments for the detection, characterization and analysis of nanomaterials, development of complete information on the risks associated with nanomaterials and the development of methods to assess the exposure to nanomaterials. Despite the studies conducted so far, we are still not able to quantitatively assess the risks involved. The toxicity of individual nanoparticles varies greatly, making it difficult to establish a common criterion. Evaluation of the toxicity of nanoparticles is carried out with respect to individual organisms: mammals, protozoa, shellfish, algae and plants. Toxicity to mammals is tested on rodents. There were few attempts to assess the health status of people occupationally exposed. Sparse studies on human cell lines revealed distinct DNA damage (Langauer-Lewowicka \& Pawlas, 2014, p. 10). Due to the lack of full knowledge of the risks posed by nanomaterials, it should be covered by multi-faceted and diverse legislation. The new provisions must be constructed on the basis of the precautionary principle and the principle of producer responsibility in order to ensure safe production, use and disposal of nanomaterials before they are placed on the market. The precautionary principle enables quick reaction in the face of possible risks to the health of humans, animals or plants, or for the protection of the environment. According to the Commission, the precautionary principle can be relied on if the phenomenon, product, or activity poses potential security risks, identified within the framework of scientific and objective evaluation, if such an assessment allows the identification with sufficient certainty of such a threat $(\operatorname{COM}(2000) 1$ final). In the case of nanomaterials, we certainly have to deal with the situation when there is no full knowledge of the risks arising from their use. This principle operates in the legal order of many countries. The European Union has included it in Art. 191 paragraph 2 of the Treaty on the Functioning of the European Union (TFEU), which results in the obligation on the part of the Member States regarding the application of this principle in their legislation. Implementation of this rule helps in the assessment of the potential danger. It is expressly stated that even if the presence of nanoparticles in the elements of the environmental or waste can be shown, it would be technically difficult to eliminate them. Therefore, the actions taken at the end of the chain of contaminants are unable to effectively prevent the potential negative consequences for the environment and human health. The European Parliament already in 2009 recommended the Member States to invest in an adequate assessment of the risks arising from the use of nanomaterials in order to supplement the knowledge gaps and rapidly develop and implement the methods of evaluation and an appropriate and harmonized metrology and nomenclature. There are no methods to assess the 
risks associated with nanomaterials, making it impossible to design effective legal mechanisms in this sphere (2008/2208(INI), (2010/C 184 E/18).

\section{THE RISK OF APPLICATION OF NANOMATERIALS}

The advantages of the development of nanotechnology are undeniable. Achievements in this area provide an opportunity for the reduction of the use of non-renewable resources and energy, reducing the amount of waste generated. The methods based on nanotechnology allow to clean and repair the environmental damage and the removal of contaminants. In the field of medical research, there has been a significant progress, already today miniature sensors or diagnostic probes and even whole testing systems are constructed, which are implanted for diagnostic purposes. Modern nanomaterials enhance the bioactivity and biocompatibility of implants, leading to a real revolution in implantology (Maliszewska-Mazur, 2010, p. 154).

We are currently seeing an intense increase in the number of products made from nanomaterials. Since the 90 s of the 20th century, there has been a visible rise in the amount of granted patents for inventions utilizing nanomaterials. Therefore, a question should be raised whether we care about safety in terms of the production, use and removal of nanotechnologies from the environment with the same commitment as about the creation of new solutions in the field of nanotechnology. Scientific studies have shown that most nanomaterials have a dual nature, their use in environmental engineering or medicine is both attractive and carries some risks resulting from the toxicity of these materials (Szponder, 2010, p. 382). The problem is that we do not entirely know this potential threat, we do not know what happens with nanoparticles or nanomaterials in the environment. The research should be focus on the answer to the question which element from the point of view of nano-risk is important - chemical composition, size, surface structure or reactivity? (Maliszewska-Mazur, 2010, p. 159). Besides, the majority of nanomaterials cannot be the subject of the already developed methods of toxicity testing and exposure scenarios. Most of these studies focus on the first generation of nanomaterials, and because the development of this technology is very quick, currently we already have the third generation of nanomaterials (Maynard, 2006, p. 31). According to the report of the French "Agency for Environmental and Occupational Health Safety" only $2 \%$ of research on nanotechnology deals with the analysis of the safety of new solutions. The Agency, citing the precautionary principle, recommends that due to the unknown, but potentially existing risks from the use of nanoparticles in everyday products it is better to withdraw from their application where the clear benefit from the use of new technologies does not exceed unknown risks (Zapór, 2012, p. 4).

Without a doubt, an important measure today is therefore the regulation of activities in the field of nanotechnology, which unfortunately is not easy, due to the use of nanotechnology in various sectors of the economy. Above all, efforts should be made to apply a uniform definition of nanomaterial. A uniform definition will facilitate the identification of materials for the needs of applying relevant provisions of the law to them. International Organization for Standardization defined the term nanomaterials as material, which external dimensions does not exceed the nanoscale or whose structure or surface structure does not fit in the nanoscale. The term "nanoscale" is defined as a range from about $1 \mathrm{~nm}$ to $100 \mathrm{~nm}$. The numerical distribution of particle sizes makes it possible to take into account the fact that nanomaterials consist mainly of many particles of different sizes in a specific distribution. In the absence of numerical determination of particle size distribution, it would be difficult to ascertain whether a material meets the definition in a situation where some particles are smaller than $100 \mathrm{~nm}$, while others are not. The Recommendation of the European Commission in 2011 defined the definition of nanomaterial as a natural, created randomly or manufactured material containing particles in a free state or in the form of an aggregate or agglomerate, wherein at least $50 \%$ or more of particles in the numerical particle size distribution has one or more dimensions in the range of $1 \mathrm{~nm}-100 \mathrm{~nm}(2011 / 696 /$ UE). In justified cases, on grounds of protection of human health or the environment, instead of the threshold of the numerical particle size distribution of $50 \%$ a value between $1-50 \%$ can assumed.

Nanomaterials are treated as one of the forms of chemical substances and, like other chemicals are subject to legal regulation of the European Union. The guidelines in this regard are defined in the 
REACH and CLP regulations. Based on the provisions of REACH and CLP it is possible to identify a potential threat at the beginning of the chain of pollution. Each nanomaterial classification under CLP will launch a number of provisions contained in numerous acts under environmental law, aimed at controlling the releases of hazardous substances into the environment.

Due to security concerns consumers must be adequately informed about the presence of a nanoingredient in the product. In May 2011, at the meeting of Inter-Organization Programme for the Sound Management of Chemicals, operating at the Organization for Economic Co-operation and Development (OECD), it was proposed to place warning phrases as follows: „Contains designed nanomaterials. Warning. Unknown threat”, „Contains designed nanomaterials. Warning. Threat is not fully characterized" (Zapór, 2012, p. 6). Scientific Committee on Emerging and Newly Identified Health Risks considers it necessary to identify the characteristics of each nanoparticle that may cause risk to human health and the environment and replace it on the label (http://ec.europa.eu/health, 7.01.2016). Within the EU, the obligation to put information about the component in the form of nanomaterials in food products is defined in the Regulation of the European Parliament and of the Council on the provision of information about food products to consumers (1169/2011). In accordance with the introduced changes, all the ingredients present in the product, in which at least half of the particles/fragments lies in the range of 1-100 nm must be preceded by the prefix „nano”. The obligation put the "nano" marking on cosmetics is defined in the Regulation of the European Parliament and of the Council on cosmetic products (1223/2009). All ingredients present in the form of nanomaterials shall be clearly indicated in the list of ingredients. The word "nano" should be indicated in brackets after the name of the ingredient. Since nanotechnology is subject to dynamic changes, EU regulatory bodies will carry out systematic reviews of the existing legislation.

\section{ETHICAL ASPECTS}

The second half of the twentieth century saw the rapid development of new technologies. The XXI century is the century of biotechnology, genetic engineering and nanotechnology. The development of biotechnology has raised a lot of controversy, despite the regulation of this sector to a large extent, there is still no consistent law regarding, for example genetic research. Due to intensive scientific research and the creation of new solutions, the EU legislator has introduced patent protection for biotechnological inventions. Although nanotechnology inventions do not arouse such controversy as biotechnology, perhaps it is worth considering whether similar solutions in the patent law for nanotechnology should be introduced in the future. In literature, one may come across the statement that these two areas, contrary to appearances, have a lot in common. Nanotechnology is based on techniques and methods of manipulating matter on the nanoscale, but it makes no difference whether it is living or inanimate matter. For this reason, it is possible to combine the essential elements of both disciplines in nanobiotechnology (Balcerzak, 2013, p. 155). To some extent, it is possible to use the legislation concerning biotechnology. Public acceptance of new technologies is a key aspect of their development. At the moment in Europe, we are seeing the controversy surrounding the nerve implants, which give new opportunities to those suffering from the Parkinson's disease or patients who require the restoration of sight. The concerns relate to the possible use of implants for purposes unrelated to treatment. The European Commission considered to take into account the expectations and concerns of the society. Nanotechnology must not only be safe and useful, but also have to gain the support of public opinion. The public must be aware of the benefits, potential risks and necessary measures related to the use of nanotechnology. Public debate should also be encouraged in order to help people in forming an independent opinion. A major role in this process should be played by scientists, explaining the principles and applications of nanotechnology to the public (COM (2009) 607).

In 2008, the European Commission adopted a code of conduct regarding the responsible research in nanosciences and nanotechnologies (Code of Conduct for Responsible Nanosciences and Nanotechnologies Research) with a recommendation to use it as an instrument for the basis of further initiatives aiming at ensuring the safety, ethical and sustainable nature of the research in nanosciences and nanotechnologies in the EU.

Compliance with the Code of Conduct is voluntary. It contains a set of general principles and guidelines 
regarding the actions to be taken by all stakeholders in the field of $N \& N$. The Code aims at improving the implementation of the existing legislation and facilitating the settlement of issues which are questionable from a scientific point of view. It is highlighted that the $\mathrm{N} \& \mathrm{~N}$ research should be conducted in accordance with the precautionary principle, anticipating the potential impact of this research on the environment, health and safety, and taking precautions, which are proportional to the required level of protection ((2008) 424).

Individual EU member states have begun the implementation of initiatives aimed at better informing the public about the development of nanotechnology. In the UK, the DEEPEN (Deepening Ethical Engagement and Participation with Emerging Nanotechnologies) project was created, which aimed to create a base for social acceptance of nanotechnology development. In the Netherlands, it was the Nanopodium program, one of the major social dialogue programs in the European Union. Belgium launched the Nanosoc program, which was to create a common platform for discussion about nanotechnology for researchers, business and society. Despite the fact that nanotechnology does not raise such controversies as biotechnology, and societies are rather positive about diagnostic and therapeutic possibilities offered by nanotechnology, they require the provision of detailed information on the longterm impact of nanoparticles on the body more and more often. In Germany, the Nanologue project was launched, which aimed to highlight the benefits and consequences of nanotechnology, as well as explain the ethical, social and legal issues associated with the use of nanotechnology, and to promote the dialogue between the public and other interested parties (http://cordis.europa.eu/home_pl.html, 12.01.2015).

Social acceptance and elimination of concerns about nanomaterials will have a positive impact on the future and the development of nanotechnology. The social dialogue should involve the representatives of the civil society and scientists, as well as other stakeholders.

\section{CONCLUSIONS}

Currently, in relation to nanomaterials, within the European Union we are dealing with both the legal acts with binding force, as well as non-binding acts such as recommendations concerning the fair conduct of scientific research or the application of a uniform definition of nanomaterial. Since nanotechnology became the object of interests of the European legislator almost twenty years, it has also been the subject of discussions regarding the legal doctrine. An important measure today is the regulation of activities in the field of nanotechnology, which unfortunately is not easy, due to the use of nanotechnology in various sectors of the economy. Above all, efforts should be made to apply a uniform definition of nanomaterial, which will facilitate the identification of materials for the needs of applying relevant provisions of the law to them. Important challenges relate primarily to establishing validated methods and instrumentation for detection, characterization, and analysis, completing information on hazards of nanomaterials and developing methods to assess exposure to nanomaterials. The importance of public debate on nanotechnology has been emphasized by several bodies in the EU. The European Commission states that the Member States should strengthen public debate on benefits, risks and uncertainties related to nanotechnology. Individual EU member states have begun the implementation of initiatives aimed at better informing the public about the development of nanotechnology. The social dialogue should involve the representatives of the civil society and scientists.

\section{LITERATURE}

Balcerzak, M. (2013). Zagadnienia nanotechnologii w prawie, Czy nanotechnologia może czerpać $\mathrm{z}$ doświadczeń biotechnologii? [The issues of nanotechnologies in law, Is nanotechnology can draw on the expertise of biotechnology?]. In D. M. Trzmielak (Ed.), Innowacje $i$ komercjalizacja $w$ biotechnologii [Innovation and commercialization in biotechnology], Poznań - Łódź, Poland: Uniwerstytet Łódzki.

Baran, A. (2015). Prawne aspekty nanotechnologii w kontekście ochrony środowiska [Legal aspects of nanotechnology in environmental protection, Economics and Environment]. Ekonomia $i$ Środowisko, 1(52), 28-40.

Bazela, M. (2008). Jakie sa największe wyzwania w dzisiejszej bioetyce? [What are the biggest challenges in today's bioethics?]. Retrieved from http://biotechnologia.pl/ bioetyka/aktualnosci/jakie-sa-najwieksze-wyzwania-w-dzisiejszej-bioetyce-maciej-bazela,11197

Brazell, L. (2012). Nanotechnology law. Best practices. Wolters Kluwer, Law\&Business, Alphen aan den Rijn. 
Commission Recommendation 2011/696/EU on the Definition of Nanomaterial (OJ L 275, 20.10.2011).

Commission Recommendation of 7 February 2008 on a code of conduct for responsible nanosciences and nanotechnologies research C(2008) 424 (OJ L 2008/116/46, 30.04.2008).

Communication from the Commission of 2 February 2000 on the precautionary principle (COM $(2000) 1$ final - Not published in the Official Journal, 2.02.2000).

Directive 2001/83/EC of the European Parliament and of the Council of 6 November 2001 on the Community code relating to medicinal products for human use (OJ L 311, 28.11.2001).

Dorocki, S., \& Kula, A. (2015). Przestrzenne zróżnicowanie nanotechnologii $\mathrm{w}$ Europie [Spatial diversity of development nanotechnology in Europe]. Prace Komisji Geografii Przemysłu Polskiego Towarzystwa Geograficznego, 29(1), 27-41.

EC/726/2004 Regulation (EC) No 726/2004 laying down Community procedures for the authorisation and supervision of medicinal products for human and veterinary use and establishing a European Medicines Agency (OJ L 136, 30.04.2004).

Falkner, R., Breggin, L., Jaspers, N., Pendergrass, J., \& Porter, R. D. (2010). International coordination and cooperation: the next agenda in nanomaterials regulation. In G. A. Hodge, D. M. Bowman, \& A. D. Maynard (Eds.), International Handbook on Regulating Nanotechnologies. Cheltenham and Northampton, Great Britain: Edward Elgar Publishing.

Ganguli, P., \& Jabade, S. (2012). Nanotechnology, Intellectual Property Rights, Research, Design and Commercialization. Boca Raton, USA: CRC Press.

Jurewicz, M. (2014). Nanotechnologia, Regulacje prawne, Legislacja Unii Europejskiej [Nanotechnology, Regulations, European Union Legislation]. Warszawa, Poland: Difin.

Langauer-Lewowicka, H., \& Pawlas, K. (2014). Nanocząstki, nanotechnologia - potencjalne zagrożenia środowiskowe i zawodowe [Nanoparticles, nanotechnology - the potential environmental and occupational hazards]. Medycyna Środowiskowa, 17(2), 7-14.

Maliszewska-Mazur, M. (2010). Nanotechnologia - nowe wyzwania, nowe możliwości i nowe problemy [Nanotechnology - new challenges, new possibilities and new problems]. Ochrona Środowiska i Zasobów Naturalnych, 45, 153-161.

Malloy, T. F. (2012). Soft law and nanotechnology: A functional perspective. Jurimetrics: The Jurnal of law, Sciences \& Technology, 52(3), 347-358.

Mapping study on regulation and governance of nanotechnologies (2009). Retrieved from http://www. nanowerk.com/nanotechnology/reports/reportpdf/ report126.pdf

Marchant, G. E., \& Doug, J. S. (2006). Transnational Models for Regulation of Nanotechnology. Journal of Law, Medicine \& Ethics, 714-725. Retrieved from http:// caat.jhsph.edu/programs/workshops/Transnational\%20models\%20for\%20reg.pdf
Matsuura, J. H. (2006). Nanotechnology regulation and policy worldwide. Norwood, USA: Artech House.

Maynard, A. D. (2006). Nanotechnology: assesing the risk, Review Feature. Nanotoday, 1(2), 22-33.

Oud, M. (2007). A European perspective. In G. A. Hodge, D. M. Bowman, \& K. Ludlow (Eds.), New global frontiers in regulation, The age of nanotechnology (pp. 97-109). Cheltenham and Northampton, Great Britain: Edward Elgar Publishing.

Ponce del Castillo, A. M. (2010). The UE approach to regulating nanotechnology. Brussels: ETUI.

Regulation (EC) No 1169/2011 on the provision of food information to consumers (OJ L 304, 22.11.2011).

Regulation (EC) No 1223/2009 of the European Parliament and of the Council of 30 November 2009 on cosmetic products (Text with EEA relevance), (OJ L 342, 22.12.2009).

Regulation (EC) No 1907/2006 of the European Parliament and of the Council of 18 December 2006 concerning the Registration, Evaluation, Authorization and Restriction of Chemicals (OJ L 396, 30.12.2006).

Regulation (EU) No 528/2012 of the European Parliament and of the Council of 22 May 2012 concerning the making available on the market and use of biocidal products (OJ L 167, 27.06.2012).

Regulatory aspects of nanomaterials (COM (2008) 366, 17.06.2008).

Sandler, R. (2009). Nanotechnology: The Social and Ethical Issues. Woodrow Wilson International Center for Scholars, Project on Emerging Nanotechnologies, PEN 16.

Scientific Committee on Emerging and Newly Identified Health Risks (2009). Risk Assessment of Products of Nanotechnologies. Retrieved from http://ec.europa. eu/health/ph_risk/committees/04_scenihr/docs/ scenihr_o_023.pdf

Second Regulatory Review on Nanomaterials (COM (2012) $572,3.10 .2012)$.

Szponder, D. K. (2010). Nanomateriały w środowisku korzyści zagrożenia [Nanomaterials in the environment - benefits and risks]. V Krakowska Konferencja Młodych Uczonych. Kraków, Poland.

The Regulation (EC) No 1272/2008 of the European Parliament and of the Council of 16 December 2008 on classification, labelling and packaging of substances and mixtures (OJ L 353, 31.12.2008).

Witek, R. (2014). Czy patentowanie może być niemoralne? [Is patenting may be immorial?]. Retrieved from http://wtspatent.pl/wp-content/uploads/2014/05/ pl4.pdf

Zapór, L. (2012). Bezpieczeństwo i higiena pracy a rozwój nanotechnologii [Occupational safety and health and nanotechnology, Occupational Safety, Science and Practice]. Bezpieczeństwo Pracy: nauka i praktyka, 1, 4-7. 